\title{
A Review: New Thoughts on Growth
}

\author{
E. M. WIDDOWSON AND R. A. $\operatorname{McCANCE}^{(33)}$ \\ Department of Investigative Medicine, University of Cambridge, Cambridge, England
}

\section{Extract}

There is a critical point in development when the size of an animal, arising from its previous plane of nutrition, determines its appetite thereafter, and hence its rate of growth and dimensions at maturity. A small size at this critical time, brought about by undernutrition, is not followed by "catchup" growth, however liberal the diet.

A full diet produces catch-up growth only if the undernutrition, whatever its cause, has occurred after this critical period is over. It can, moreover, only restore a young animal to its percentile channel of growth, and its ability to do this after long periods of undernutrition becomes progesssively limited by the animals chronologic age when the catch-up growth became possible.

\section{Speculation}

Many of the determinants of growth and form are known but the results have presented difficulties in interpretation and have not been synthesized hitherto into a coherent whole. The present paper outlines a theory directed to this end.

\section{PERCENTILE GROWTH CURVES}

When growth first came to be studied systematically the heights and weights of children at all ages were collected gradually, and, in the course of time, this led to the production of the so-called percentile growth curves $(23,25)$. Although these had been compiled by the cross-sectional method, which is known to have serious limitations in the case of individuals, it became apparent quickly that any healthy child tended to grow along one of these curves which could be predicted from its dimensions when first seen. This has in fact been used to predict the height a child is likely to attain (2, 22 ), even though quite large temporary deviations from this curve are possible at puberty $(6,24)$.

The failure of the growth of a healthy child to follow its growth curve may have a physiologic or a pathologic cause. The children of small mothers, for example, who are often themselves small at birth, may move up to a higher curve and adhere to it if their fathers have been tall. Walton and Hammond (26) showed the dramatic effects such nutritional and genetic influences might have when they crossed large and small breeds of the horse. We shall be concerned in this article with children whose growth has fallen well below their expected growth curve for nutritional reasons. If the obstacle to their taking enough food is removed these children characteristically exhibit what has been called catch-up growth (18). They eat voraciously, grow very rapidly at first, and, as they approach the curve they originally left, they begin to eat less and grow more slowly till their rate of growth gradually merges into it. Animals such as pigs and guinea pigs behave in the same way, and cattle may exhibit successive waves of growth as their food supply varies with the seasons. The energy value of the food eaten voluntarily during the period of catch-up growth is usually about the amount characteristically eaten by a younger well nourished child or animal of the same size, but it may be more (see below). The rate of catch-up growth varies with the energy value of the food consumed, and the food is converted to new tissue in the normal way $(1,9$, 21).

The experimental work both on rats and pigs has brought out a further fact about catch-up growth. It is only complete if the period of undernutrition has been relatively brief (31). Furthermore, it becomes less and less complete as the period of undernutrition is prolonged $(13,14)$, and this has been attributed to the progressive effect of age.

\section{CELL DIVISION AND CELL ENLARGEMENT}

Winick and Noble (32) made a valuable contribution to the study of growth by pointing out that growth took place in three stages. They stated that, for the first 21 days after birth in the rat all organs grow mainly by cell division, but that between 21 and 42 days, growth of the organs proceeded by both cell division and cell enlargement. By the end of this time, however, cell division had ceased in the brain and lung so that thereafter the lung could increase in weight only by cellular enlargement. This principle may very well be true of the brain, or, at any rate, of certain parts of the brain (4). Winick and Noble (32) went on to point out that from 42 to 65 days, growth of organs other than the brain and lung continued both by cell division and enlargement, but cell division had ceased by the end of this time except in the lymphoid tissue. Any further increase in weight could, consequently, only result from cellular enlargement. Furthermore, if cell division were delayed by undernutrition beyond the normal time at which it came to an end, it could not be restarted by subsequent rehabilitation. Rehabilitation could, however, restore cells to their full size at any age, no matter how much they had failed to hypertrophy or had decreased in size during the period of undernutrition. Winick and Noble (32) did not study the effects of prolonging the period of undernutrition after weaning until the age when growth is normally over, and so failed to see the difficulties raised by the results of McCay et al. (14), that undernutrition might delay the processes of cell division for years, even in a rat, without preventing it from being restarted by rehabilitation. Winick and Noble were also not aware of the progressive effect of age.

\section{CRITICAL PERIODS IN DEVELOPMENT}

The whole developmental life of an animal may be profoundly altered by events during a very short period in it. These have been termed the critical periods of development (7). Studies initiated by Barraclough (3) and Harris and Levine (5) are good examples of the effects of interference at one of these critical points. These authors showed that the injection of a single dose of testosterone into a female rat or of estradiol into a male rat 5 days after birth completely wrecked the sexual physiology of the animal for the rest of its life.

A full term infant has reached a fairly advanced stage of development by the time it is born, as has a pig, and even more so a guinea pig or a horse. Even a very premature baby is in a 
more advanced stage of development than a rat born after its normal period of gestation. Experiments, therefore, involving critical periods of development can be made on a full term rat after birth which can be made on a pig or a guinea pig only before birth and which would be quite unethical to make on a human being. This is one of the things which has made the rat such a valuable animal for the study of developmental physiology.

Widdowson and. McCance (30), McCance and Widdowson (12), and Widdowson and McCance (31) described the results of rearing rats during the suckling period in small groups of 3 and large groups of 15 or more. At weaning, rats suckled in small groups were usually 2-4 times larger than those suckled in large groups. At weaning, all of the rats were placed upon a stock diet, ad libitum. The smaller rats suckled in large groups were not ravenously hungry, and did not eat enough food to enable them to catch up to their larger littermates in weight, nor did they show any signs of doing so. Rats undernourished for the same length of time $9-12$ weeks after birth were very hungry, and did catch up when they were allowed enough food to enable them to do so. That is to say, they returned to the curve along which they had been growing. If this curve was at a lower level than it should have been because of a nutritional set-back during the critical period earlier in their development, then the animals returned to this lower curve, and not to the higher one characteristic of animals well nourished throughout their lives. The conclusion drawn by Widdowson and McCance was that the earlier in the life of the animal the undernutrition was imposed the more serious and permanent its effects would be.

Widdowson and McCance (31) also found that if the period of undernutrition lasted from weaning at 3 weeks until 12 weeks rats did not catch up in weight. There was an incipient catch-up effect, but this came to an end before the animals had returned to their percentile growth channel.

An animal previously undernourished and then provided with a plentiful supply of food will therefore respond in three different ways according to its age when the undernutrition is imposed and the length of time for which undernutrition lasts. The critical period in the development of the rat is during the suckling period. The appetite and other regulating centers in the hypothalamus are being integrated with the size of the developing organism at that time (28). The plane of nutrition up until this time, and consequently the size the animal has reached, determine what its final size will be, even though this may be smaller than its genetic legacy. If this premise is correct, it should only be possible to produce the same effect in animals born at a much later stage of development than the rat by imposing the period of undernutrition well before birth. This has now been done in pure bred pigs and guinea pigs (13, 29) and the anticipated result (i.e., no catch-up growth) has been obtained. The hypothalamus has certainly been organized before birth in man, and this is the main reason why the growth rates of healthy newborn infants and children tend to follow their own pre-selected percentile line.

The 9 th to the 12 th week of a rat's life is certainly not a critical period in its development. It is a short period, moreover, relative to the time taken by a rat to achieve its full size and it falls within Winick and Noble's third stage of growth. The catch-up growth in the rat after undernutrition for 3 weeks at this age is probably comparable to the catch-up growth in some children recorded by a number of authors $(10$, 18).

The secular trends in height and weight, and observations and experiments such as those of Ross $(19,20)$, Oppers (17), and Malcolm $(15,16)$, all indicate that a period of suboptimal nutrition during most of the growing period has three effects. (1) It makes the young animal or the child grow at a suboptimal rate. (2) The time during which growth is possible is prolonged. (3) In spite of this the result is a smaller adult. We regard the experiments of Widdowson and McCance (30) and McCance and Widdowson (13) on prolonged periods of undernutrition followed by rehabilitation in rats and pigs, of Lister et al. (8) in cockerels, and, in their most extreme form perhaps, those of McCay et al. (14) in rats, as being examples of the same phenomenon and one of the well known, but still mysterious processes of aging.

\section{ROLE OF APPETITE}

The rate of growth of all animals before birth depends mainly upon the quantity of nutrients reaching the fetus by the blood; however, in animals like the rat, which are born at a very early stage of development, the rate of growth for a time after birth depends upon the quantity of nutrients reaching the organisms by the mouth. As already pointed out, at some point during suckling comes the critical period when the centers in the hypothalamus are being organized in accordance with the size of the growing organism at that time. Thereafter, the responsibility of appetite, whether conscious or unconscious, is to ensure that the intake of nutrients is slightly more than enough to meet the current expenditure on growth and all the other activities of the body. At what time before birth appetite could begin to function in pigs, guinea pigs, or man we do not know, but it is certainly ready to come into action immediately after birth in these animals and is fully functional in rats when they are weaned at 21 days of postnatal age. Consequently, small rats suckled in large groups and large rats suckled in small groups eat according to their activities and size and have no abnormal feelings of hunger. All accumulate the appropriate amounts of fat in their bodies. The same is true of pigs and guinea pigs. The small ones therefore grow up, but they do not catch up.

While the child or animal is growing rapidly, and in certain persons later in life, the appetite seems to be "set" to encourage the intake of a small excess of energy every day, and the sensors of the body are very tolerant of this. Consequently, considerable deposits of fat may take place before the regulating centers take any corrective action, and in fact it seems to be "physiologic" for fat to be deposited in the body during the first weeks or months after birth. Quite the reverse is true when the intake of energy falls below the animal's immediate requirements even by relatively small amounts. The sensors of the body then react at once, hunger begins to operate, and the more the stores of energy are depleted the more the drive to eat becomes accentuated and the more the animal or man is prepared to eat at any one meal or on any one day $(10,11)$. Whatever its age, the animal, if undernourished, will eat not only the amount appropriate for its size or weight but often, for a time, considerably more. Adults regain their original weight and may exceed it before their intake levels off (27). Children and young animals may catch up very rapidly at first. As they approach their percentile growth channel their intake levels off and their rate of growth slows down. They end by rejoining their channel unless age prevents them so doing.

\section{REFERENCES AND NOTES}

1. Ashworth, A.: Growth rates in children recovering from proteincalorie malnutrition. Brit. J. Nutr., 23; 835 (1969).

2. Bayley, N.: Individual patterns of development. Child development. 27: 45 (1956).

3. Barraclough, C. A.: Production of anovulatory, sterile rats by single injections of testosterone propionate. Endocrinology, 68: 62 (1961).

4. Dobbing, J., and Sands, J.: The later development of the central nervous system and its vulnerability. In: J. A. Davis and J. Dobbing: Scientific Foundation of Paediatrics, p. 565 (Heinemann, London, 1974).

5. Harris, G. W. and Levine, S.: Sexual differentiation of the brain and its experimental control. J. Physiol., 163: 42P (1962).

6. Israelsohn, W. J.: Description and modes of analysis of human growth. In: J. M. Tanner: Human Growth: Symposia of the 
Society of Human Biology, Vol. 3 p. 21 (Pergamon, London, 1960).

7. Kazda, S., and Denenberg, V. H.: The post-natal development of phenotype (Academia, Prague, 1970).

8. Lister, D., Cowen, T., and McCance, R. A.: Severe undernutrition in growing and adult animals. 16. The ultimate results of rehabilitation: Poultry. Brit. J. Nutr., 20: 633 (1966).

9. McCance, R. A.: Severe undernutrition in growing and adult animals. 1. Production and general effects. Brit. J. Nutr., 14: 59 (1960).

10. McCance, R. A.: Malnutrition in Uganda. Proc. Nutr. Soc. India, 10: $132(1970)$.

11. McCance, R. A.: The Composition of the body: Its maintenance and regulation. Nutr. abstr. Rev., 42: 1269 (1972).

12. McCance, R. A., and Widdowson, E. M.: Nutrition and growth. Proc. Roy, Soc. London Ser. B, 156: 326 (1962).

13. McCance, R. A., and Widdowson, E. M.: The determinants of growth and form. Proc. Roy. Soc. London Ser. B, 185: 1 (1974)

14. McCay, C. M., Maynard, L. A., Sperling, G., and Barnes, L. L. Retarded growth, life span, ultimate body size and age changes in the albino rat after feeding diets restricted in calories. J. Nutr., 18: 1 (1939).

15. Malcolm, L. A.: Growth and development in New Guinea-A study of the Bundi people in the Madang district. Monograph Series 1, Institute of Human Biology, Papua, New Guinea, 1970.

16. Malcolm, L. A.: Growth and development of the Bundi child of the New Guinea highlands. Human Biol., 42: 293 (1970).

17. Oppers, V. M.: Analyse van de acceleratie van de menselijke lengtegroei door bepaling van het tijdstip van de groeifasen. Amsterdam, M.D. thesis, 1963.

18. Prader, A., Tanner, J. M., and von Harnach, G. A.: Catch up growth following illness or starvation: An example of developmental canalization in man. J. Pediat., 62: 646 (1963).

19. Ross, M. H.: Protein, calories and life expectancy. Fed. Proc., 18: 1190 (1959).

20. Ross, M. H.: Length of life and nutrition in the rat. J. Nutr., 75: 197 (1961)

21. Rutishauser, I. H. E., and McCance, R. A.: Calorie requirements for

Copyright @ 1975 International Pediatric Research Foundation, Inc. growth after severe undernutrition. Arch. Dis. Childhood, 43: 252 (1968).

22. Sinclair, D.: Human growth after birth. (Oxford University Press: London, 1969).

23. Stuart, H. C., and Stevenson, S. S.: In: W. E. Nelson: Textbook of Pediatrics, Ed. 8, p. 48 (Saunders, Philadelphia, 1954).

24. Tanner, J. M.: Education and physical growth. (University Press, London, 1963).

25. Tanner, J. M., Whitehouse, R. H., and Takaishi, M.: Standards from birth to maturity for height velocity, and weight velocity: British Children, 1965. Arch. Dis. Childhood, 41: Part 1, 454, Part 2, $613(1966)$

26. Walton, A., and Hammond, J.: The maternal effects on growth and conformation in Shire horse-Shetland pony crosses. Proc. Roy. Soc. Lond. B, 125: 311 (1938).

27. Widdowson, E. M.: The response to unlimited food. Studies of undernutrition, Wuppertal 1946-1949. Med. Res. Council Spec. Rep. Ser., 275: 313 (1951)

28. Widdowson, E. M.: Food intake and growth in the newly-born. Proc. Nutr. Soc., 30: 127 (1971).

29. Widdowson, E. M.: Intra-uterine growth retardation in the pig. 1. Organ size and cellular development at birth and after growth to maturity. Biol. Neonate, 19: 329 (1971).

30. Widdowson, E. M., and McCance, R. A.: Some effects of accelerating growth. 1. General somatic development. Proc. Roy. Soc. London Ser. B, 152: 188 (1960).

31. Widdowson, E. M, and McCance, R. A.: The effect of finite periods of undernutrition at different ages on the composition and subsequent development of the rat. Proc. Roy. Soc. London Ser. B. 158: 329 (1963)

32. Winick, M., and Noble, A.: Cellular response in rats during maturation at various ages. J. Nutr., 89: 300 (1966).

33. Requests for reprints should be addressed to: E. M. Widdowson, D.Sc., Department of Investigative Medicine, University of Cambridge, Downing Site, Downing Street, Cambridge CB2 1 QN (England).

34. Accepted for publication February 28, 1974.

Printed in U.S.A. 